\title{
Mycobacteriosis in Wild Birds: the Potential risk of Disseminating a Little-known Infectious Disease
}

\section{Micobacteriosis en aves silvestres: Riesgo potencial de diseminación de una infección poco conocida en el mundo}

\author{
Diego Soler ${ }^{1}$, Claudia Brieva ${ }^{1}$ y Wellman Ribón ${ }^{2}$
}

\author{
1 Facultad de Medicina Veterinaria y de Zootecnia, Universidad Nacional de Colombia, \\ dsolert@gmail.com, cibrievar@unal.edu.co \\ 2 Subdirección de Investigación, Instituto Nacional de Salud, Bogotá, Colombia. wribon@ins.gov.co \\ wellmanribon@yahoo.es
}

Received $3^{\text {th }}$ July 2008/Sent for Modification $24^{\text {th }}$ December 2008/Accepted $14^{\text {th }}$ January 2009

\begin{abstract}
Avian mycobacteriosis is important for animal and human health; wild birds play an important role in mycobacterial species' ecology and movement. This review was aimed at reporting the role of birds in the spread of avian mycobacteriosis in human and animal populations at risk and thus a systematic review was made of PubMed, Science Direct, Scielo and Scirus databases. Mycobacteria are classified into the Mycobacterium tuberculosis complex and non-tuberculous mycobacteria; the Mycobacterium avium complex represents the most important part of the latter because it is primarily responsible for mycobacterial infection in wild birds and is a potential pathogen for mammals, especially for immunocompromised patients. The clinical signs in birds are variable as it is a chronic and debilitating disease, involving emaciated carcasses, white nodules in different organs and microscopically it presents granulomatosous multifocal inflammation. Diagnosis begins by suspicion based on clinical signs and finishes with microbiological confirmation. New diagnostic techniques include testing with DNA-RNA probes. No effective treatment is currently available and chemoprophylaxis on suspicion of infection is not recommended at the start; these factors increase the potential risk of mycobacteriosis becoming one of the most frequently documented zoonotic diseases which is difficult to treat in birds and humans. Recent concern regarding mycobacterial infection lies in the increased frequency of these opportunistic infections occurring in immunocompromised individuals and these infections' potential impact on bird conservation, this being increased by greater contact between humans and wild and captive birds.
\end{abstract}

Key Words: Atypical Mycobacterium infection, wild animal, bird (source: MeSH, NLM).

\section{RESUMEN}

La micobacteriosis aviar es de importancia para la salud animal y humana. El objetivo de esta revisión fue reportar el papel de las aves en la diseminación de la 
micobacteriosis aviar en poblaciones vulnerables. Se realizó una revisión sistemática en las bases de datos PubMed, Science Direct, Scielo and Scirus. Las aves silvestres juegan un papel importante en la ecología y movimiento de micobacterias. Estas se clasifican en el Complejo Mycobacterium tuberculosis y las micobacterias no tuberculosas, dentro de este último grupo se destaca el Complejo Mycobacterium avium, principal responsable de micobacteriosis en aves silvestres y patógeno potencial para los mamíferos principalmente pacientes inmunosuprimidos. Los signos clínicos son variables, siendo una enfermedad debilitante y crónica, e involucra carcasas emaciadas, nódulos blanquecinos en diferentes órganos, microscópicamente presenta inflamaciones granulomatosas multifocales. El diagnóstico inicia por la sospecha basada en los síntomas clínicos y termina con la confirmación microbiológica. Adicionalmente, las nuevas técnicas diagnósticas incluyen pruebas con sondas de ADN-ARN. Actualmente, no existe un tratamiento efectivo y no se recomienda iniciar quimioprofilaxis; estos factores incrementan el riesgo potencial para convertir la micobacteriosis aviar en una enfermedad zoonótica más frecuente de lo documentado y de difícil tratamiento en aves y humanos. La reciente preocupación de las infecciones micobacterianas, radica en el aumento de la frecuencia de estas infecciones oportunistas en personas inmunocomprometidas y el impacto potencial de estas infecciones sobre la conservación de las especies de aves, favorecido por el mayor contacto entre humanos y aves tanto silvestres como cautivas.

Palabras Clave: Infecciones atípicas por Mycobacterium, animales salvajes, aves (fuente: DeCS, BIREME).

$\mathrm{B}$ irds can become involved in the dispersal of microorganisms as biological and mechanical carriers or become infected with blood ectoparasites $(1,2)$. Many vertebrate's pathogenic microorganism species are associated with healthy birds; such birds could play a significant role in microorganismecology and migration $(1,3)$. The efficiency of microorganism dispersion depends on both biotic (i.e. vertebrate host or invertebrate vector susceptibility and the persistence of agents in the environment) and abiotic factors (i.e. temperature and humidity affecting the agents' survival or their becoming scattered from habitats or ecosystems into new geographical areas) (1-3).

The current status of avian mycobacteriosis in nature or in captivity is hardly known, nor is their dispersion by bird species in Latin-America. This article reports the role of birds regarding the potential risk of infectious diseases (e.g. avian mycobacteriosis) becoming disseminated for vulnerable populations such as those infected by human immunodeficiency virus (HIV), and other chronic and debilitating diseases such as cancer, diabetes, lupus and those of extreme ages such as children and old people who are predisposed ipso facto to infection by mycobacteria. 
A systematic search of the PubMed, Science Direct, Scielo and Scirus databases was thus made using the following words in all possible MeSH (Medical Subject Heading) term combinations: avian mycobacteriosis, avian tuberculosis, Mycobacterium infection, $M$. avium complex and wild birds. This was complemented by reviewing wildlife medicine reference books. Articles published from 1975 to 2007 were selected which reported generalities regarding mycobacteria in wild birds, their clinical characteristics and diagnosis and importance in animal and human health.

Mycobacteria and wild animals

Mycobacteria are acid-fast bacilli, acidophilic, small and slightly curved. They are aerobic, immobile and non-sporulated bacteria. Their cell wall is lipid-rich, forming smooth to wrinkled colonies when cultured in solid medium; some are pigmented $(3,4)$. Their high concentration in lipid cells is responsible for their resistance to immune system defence mechanisms and disinfectants $(3,5)$. Mycobacterium tuberculosis complex species are recognised as being the cause of tuberculosis in mammals, although $M$. tuberculosis and $M$. bovis have been reported in birds and other species $(3,4)$. Another important group in human and veterinary medicine consists of non-tuberculous mycobacteria (NTM), these being opportunistic saprophytes causing mycobacteriosis in animals (Table 1) (3-6).

Table 1. Mycobacterial species and the wild hosts affected by them

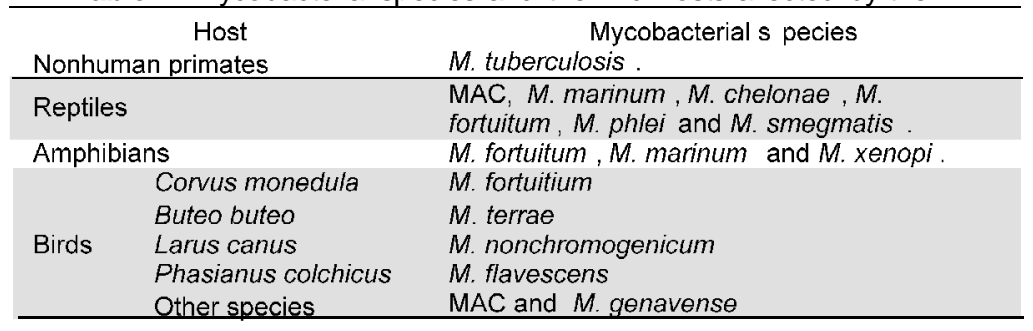

The M. avium complex (MAC) consists of opportunistic pathogens capable of causing disease in animals and humans $(4,7)$. MAC has 28 serotypes from $M$. avium and $M$. intracellulare species (7-9). Serotype 1 is most frequently reported in North-American birds whilst serotype 2 is more commonly reported in Europe. Serotype 3 has been sporadically isolated in European birds and 2 and 3 are more highly pathogenic than serotype 1 . Serotypes 1,4 and 8 are most frequently isolated from humans (11). 
Several types of mycobacterial disease occur in vertebrates. Mycobacteria cause disease in mammals, birds, reptiles, amphibians and fish (Table 1) (2,13-17); they are considered to be globally distributed and occur only occasionally due to the few studies published so far (14).

Avian mycobacteriosis

Three types of lesion are caused by mycobacteria in birds: the tubercular, focal or multifocal form, the disseminated or diffuse form and the paratuberculous form in the gastrointestinal tract $(11,19)$. Its clinical presentation varies greatly, thereby hampering ante-mortem diagnosis (20).

MAC (and more recently $M$. genavense) is the mycobacteria which has been most commonly isolated from domestic and wild birds and humans (Table 1) $(10,13,15,20,21,22)$. Some zoos have set up avian mycobacterial collections of valuable specimens catalogued as being rare or in danger of extinction. The cost of replacing such valuable animals thus emphasises the importance of these mycobacterial species' timely diagnosis $(9,11,14,16,17,26,27)$.

\section{Epidemiology}

\section{Distribution}

Avian mycobacteriosis is a worldwide disease affecting all birds, whether living free or in captivity in one form or another $(2,9,12,20,29,30)$. This disease occurs most commonly in temperate zones in northern and tropical areas; mycobacteriosis is not usually reported in tropical areas and has been poorly investigated. Its distribution in healthy wild birds is inferred from birds sent for necropsy; however, sampling underestimates the geographical distribution and frequency of species' infection $(12,30)$.

Incidence and prevalence

Mycobacterial infection incidence in birds remains unknown and varies depending on the species, age, housing conditions and whether birds are living in captivity or the wild. The incidence detected during avian necropsy has ranged from $0.5 \%$ to $14 \%(21,25,31,32)$. Mycobacterial infection prevalence in wild birds has not been determined, although usually at least 1 per cent of birds examined postmortem are affected. Some authors have stated that mycobacterial infections have a more important effect on captive birds than wild ones (12). 
Susceptible species

Avian mycobacteriosis has been reported in many species of birds $(17,24,25,33,34)$, but MAC and $M$. genavense are also potential pathogens for mammals, particularly if they are immunosuppressed $(2,12,13,15,19)$. Mycobacterial infection has been reported in parrots $(11,19,25,35)$, raptors $(2,9,19,22,23,25,27,29,31,36-38)$, doves and pigeons $(2,19,28,39)$, cranes $(27,33,34,36,40,41)$, musofagides and ratites $(42,43)$, ducks $(11,26,44)$, songbirds $(11,26)$, toucans $(45)$, flamingos $(46-49)$ and turkeys (21).

It is rare to see mycobacterial infection in birds aged less than 2; the disease is more common in poultry and older aquatic species due to the microorganism's long incubation period, the cumulative risk of exposure and decreased immune response. Peak incidence in parrots has been reported as being 3 to 10 years of age $(1,20,25)$. For unknown reasons, females appear to be more commonly infected than males in postmortem surveillance and clinical reports (25). Another factor influencing susceptibility to infection is the type of mycobacteria involved; some are more pathogenic to some other bird species (25).

Susceptibility to mycobacterial infection in humans is closely related to the immune response, as a poor host immune response to mycobacteria may lead to replication thereby causing infection and illness $(1,15,25,50)$. Although the host responds appropriately and controls mycobacterial infection, it does not necessarily resolve it. Mycobacteria living within macrophages in the host have replicated at subclinical levels for years to develop the active infection when the host's immune system is less efficient or has been immunocompromised $(1,15,25)$.

\section{Transmission}

Avian mycobacteriosis is often associated with areas having high animal concentrations and/or a contaminated environment; such areas where birds are congregated should be recognised as potential danger spots as such conditions are more common in captive birds $(25,34)$. It is mainly transmitted by inhaling and ingesting contaminated food or water $(3,11,12,14,21,22,25,31,36)$ when infected adults are feeding with their young and/or direct contact with infected birds' bodily excretions or carcasses $(3,10,11,12,14,21,25)$.

\section{Clinical signs}

The signs of infection in birds are variable and non-specific during infection or disease and may pass unnoticed, thereby hampering its diagnosis in live birds (25, 23, 29, 33, 51). Mycobacterial infection should be suspected in birds suffering 
chronically debilitating disease, although it should also be considered in acute deaths $(11,12,21,23,25,26,44,48,52)$. Death occurs after progressive weight-loss and muscular atrophy $(11,23,27,29,34,52)$. Affected animals generally exhibit signs of depression, weakness, anorexia and fever $(12,17,22,25)$. There may also be diarrhoea, polyuria, arthritis, claudication, pathological fractures, ascites and subcutaneous tumours $(11,12,23,25)$.

\section{Clinical pathology}

Polycromasy is most consistently observed (with or without anaemia) (25). Persistent lymphopenia has also been reported; this is regarded as being an indicator of advanced mycobacterial infection but a normal lymphocyte count does not exclude a diagnosis of disseminated mycobacterial infection $(29,52)$ and may be concurrent with eosinophilic monocytosis by granulomatous inflammation. Thrombocytosis has been reported but has been very diverse (50\% in domestic birds but only $6 \%$ in cranes) $(25,29,52)$. Hypoalbuminaemia caused by gastrointestinal loss and decreased hepatic production may be present $(25,29)$. Hepatic enzyme values may be abnormal in birds having marked hepatomegally (25).

\section{Macroscopic findings}

Primary lesion location indicates the exposure route; intestinal lesions suggest mycobacterial intake in contaminated food and water whilst lesions in the lungs and other areas of the respiratory tract suggest inhalation as being the exposure route (12). Typical cases of avian mycobacteriosis in wild birds involve lack of subcutaneous and mesenteric fat accompanied by severe atrophy of pectoral muscle, characteristic white, gray or yellow nodules and hepatosplenomegally $(12,21,27,29,34,41,48,52)$. Granulomatous lesions may be found in the lungs, spleen, intestines, bone marrow, heart, gonads, skin and joints (hepatic lesions predominating) (3,9,11,12,14,20-23,25,27$29,36,37,40,48,52,53)$. Unusual lesions have included necrotic ulceration of the tongue and chronic granulomatous lesions located in the dermis around the nostrils and retro-orbital and sinus infraorbitary tissues $(11,12,20,29,37)$.

\section{Microscopic findings}

Lesions appear as a focus of epitheloid cells (macrophages) early in the course of the disease. Because the disease is progressive, tubers are often characterised by a well-defined area of central necrosis surrounded by a capsule $(9,17,22,23,40)$. Multifocal granulomatous inflammation is severe and multifocal, with acidophilus bacilli within lesions $(20,21,26,27,29,34,38,41,42,46)$. 


\section{Diagnosis}

Ante-mortem diagnosis is based on clinical signs, leukograme, serology, culture and resistant acid alcohol stain or biopsy samples of animal fluids or organs $(11,19,25,29,37)$. Radiography, ultrasonography and coelomoscopy are useful in the medical evaluation of birds $(25,29)$.

The benchmark test for diagnosing mycobacterial disease is bacterial growth in culture (53). However, this delays its clinical usefulness in many situations because the culture is not available in less than two weeks and some species, such as $M$. genavense, are difficult to isolate by standard culture techniques $(24,32,51,54)$. The enzymatic linked immunoassay (ELISA) has been used for detecting antimycobacterial antibodies in the serum of certain species having clinical significance $(9,17,42)$. New techniques include diagnostic deoxyribonucleic acidribonucleic acid (DNA-RNA) and polymerase chain reaction (PCR) tests for specific mycobacterial genes $(9,10,11,13,15,20,21,25,28,29)$. Polymorphism restriction analysis (PRA) is used for identifying mycobacterial species and subspecies $(8,10,42,55)$. Another DNA cleavage technique involves pulsed-field gel electrophoresis which identifies subspecies within a group. Sequencing the organism is also important (42).

Treatment, control and prevention

No studies were found showing that treatment has been effective and initiating chemoprophylaxis therapy is not recommended because mycobacteria are highly resistant to antibiotics $(11,14,23,29)$. Moreover, there is the risk of creating resistance in potentially zoonotic mycobacteria, especially if the species involved are not known $(17,26,50)$.

Affected individuals' euthanasia is the most frequent recommendation. $(11,12,18)$. Controlling the disease is difficult; decreasing population density is recommended, in addition to strict hygiene (26).

It must be ensured that animals purchased for zoo collections or colonies are disease-free by using leukogrames, laparoscopy and measuring proteins $(17,27)$. Quarantine should be compulsory for new animals; the period should extend for a minimum of 60 days (17). Vaccination is not an effective option as no vaccine is available, nor has the matter been scientifically studied $(1,20,56)$. 


\section{Zoonotic potential}

The risk of NTM being transmitted to immunocompetent adult humans appears to be extremely small $(7,8,11,12,32)$. However, there is a significant risk of transmission to children and immunocompromised individuals. Humans receiving steroid therapy, chemotherapy or other immunosuppressive medication and patients infected with HIV, AIDS or leukaemia should be carefully considered regarding their possession or coming into contact with birds proving positive for mycobacterial infection. Preventative measures should be taken regarding visiting national parks and zoos $(12,25,37,57)$. Several clinical manifestations of avian mycobacteriosis occur in human patients $(7,10,11)$. Treating avian mycobacteriosis in humans has had limited success because NTM are resistant to antituberculous drugs. The clinical signs, diagnosis and treatment of NTM infection in humans have been described previously $(7,11)$.

\section{Conclusions}

Information regarding mycobacterial infection in birds is relatively limited and incomplete. This is due to a lack of information about the apparently long incubation period, inadequate proof of identification, difficulty in detecting infected birds, the broad spectrum of disease signs in birds and a lack of funding (the disease is not considered economically significant within a veterinarian context) $(12,16)$.

Recent advances in identifying mycobacterial species have led to improved diagnosis and determining which species may be causing avian disease. The usual methods for identifying Mycobacterium species have been based on their bacteriological characteristics; however, biochemical tests are not accurate for these species' phenotypic differentiation and most laboratories have reported isolating at least one member of the MAC. Using PCR and sequencing bird samples is important as culturing is very slow in terms of clinical usefulness in many situations and a faster diagnostic test having similar or greater sensitivity is needed and $M$. genavense is a relatively common pathogen in birds but does not grow on conventional media $(8,24,51,54,58)$.

The recent concern about diagnosing and treating mycobacterial infections has resulted from opportunistic mycobacterial infections occurring in AIDS patients $(7,57,59)$. Increasing contact between humans and wildlife, either in captivity when visiting zoos or having wildlife as pets (which is unsuitable) or in the wild with the rise of ecotourism and increasing colonisation of wilderness areas has thereby led to increasing contact between wild animals and humans and the subsequent 
transmission and spread of pathogens (30). For example, an estimated 33.2 million people worldwide are living with HIV/AIDS, 2.5 million of whom are children under 15 years old; 1.6 million of these adults and children are living in LatinAmerica (59). On the other hand, it is estimated that 24.6 million people are living with lung, breast and colorectal cancer (three year diagnosis) (60). They would thus be examples of human populations at risk of contracting this type of disease by coming into close contact with wildlife •

Acknowledgements. We would like to thank Dr. Miguel D. Saggese of the Western University of Health Sciences (California, USA) for his valuable contributions and Jason Garry for extensively revising and correcting the manuscript.

\section{REFERENCES}

1. Cromie R, Brown M, Price D, Stanford J. Susceptibility of captive wildfowl to avian mycobacteriosis: the importance of genetic and environmental factors. Tubercle 1991; 72: 105-109.

2. Hubalek Z. An annotated checklist of pathogenic microorganisms associated with migratory birds. J Wild Dis 2004; 40(4): 639-359.

3. Carter G, Wise D. Mycobacterium. In: Essentials of Veterinary Bacteriology and Mycology. Sixth Edition. lowa: lowa State Press; 2004. p. 207-213.

4. Nicolet J. Mycobacterium. En: Compendio de Bacteriología Médica Veterinaria. Zaragoza: Editorial Acribia; 1985. p. 184-196.

5. Brooks G, Butel J, Ornston L. Micobacterias. In: Brooks G, Butel J, Ornston L. Microbiología Médica de Jawetz, Melnick y Adelberg. $15^{\text {th }}$ ed. México: Editorial Manual Moderno; 1996. p. 323334.

6. Barragan $\mathrm{K}$, Brieva $\mathrm{C}$. Tuberculosis y micobacteriosis en primates neotropicales en cautiverio: un enfoque desde la conservación. Rev Med Vet Zoot 2005; 52(2): 128-143.

7. Inderlied C, Kemper C, Bermudez L. The Mycobacterium avium complex. Clin Microbiol Rev 1993; 6(3): 266-310.

8. Palma M, Roxo E, Cardoso S. Discrimination of members of the Mycobacterium avium complex by polymerase chain reaction. Rev Microbiol 1998; 30: 144-148.

9. Hoenerhoff M, Kiupel M, Sikarskie J, Bolin C, Simmons H, Fitzgerald S. Mycobacteriosis in an American Bald Eagle (Haliaeetus leucocephalus). Avian Dis 2004; 48: 437-441.

10. Aranaz A, Liebana E, Mateos A, Dominguez L. Laboratory diagnosis of avian mycobacteriosis. Semin Avian Exotic Pet Med 1997; 6(1): 9-17.

11. Altman R, Clubb S, Dorrestein G, Quesenberry K. Avian Medicine and Surgery. Philadelphia: W.B. Saunders Company; 1997. p. 1070.

12. Friend M, Franson J. Mycobacteriosis. In: Field manual of wildlife diseases, general field procedures and diseases of Birds. US Department of the Interior - US Geological Survey, Biological Resources Division, Information and Technology, Report 199-001. Washington, DC; 1999. p. 93-98.

13. Crawford G, Ziccardii M, Gonzales B, Woods L, Fischer J, Manning E, et al. Mycobacterium avium subspecies paramycobacteriosis and Mycobacterium avium subsp. avium infections in a Tule Elk (Cervus elaphus nannodes) Herd. J Wild Dis 2006; 42(4): 715-723.

14. Fowler M. Miscellaneous Avian Infectious Diseases: Mycobacteriosis. In: Fowler M. Zoo and Wild Animal Medicine. $2^{\text {nd }}$ ed. Philadelphia: W.B. Saunders Company; 1986. p. 230.

15. Harrenstien L, Finnegan M, Woodford N, Mansfield K, Waters W, Bannantine J, et al. Mycobacterium avium in Pygmy Rabbits (Brachylagus idahoensis): 28 Cases. J Zoo Wildl Med 2006; 37(4): 498-512. 
16. Lisle G, Bengis R, Schmitt $S$, O'Brien D. Mycobacteriosis in free-ranging wildlife: detection, diagnosis and management. Rev Sci Tech Off Int Epiz 2002; 21(2): 317-334.

17.Thoen C. Mycobacteriosis and other mycobacterial diseases in captive wild animals. In: Fowler M. Zoo and Wild Animal Medicine Current Therapy 3. Philadelphia; W.B. Saunders Company; 1993. p. 45-49.

18. Hoop R. Public health implications of exotic pet mycobacteriosis. Semin Avian Exotic Pet Med 1997; 6(1): 3-8.

19. Fowler M. Zoo and Wild Animal Medicine Current Therapy 3. W.B. Philadelphia: Saunders Company; 1993. p 226, 239, 241.

20. Gonzalez M, Rodriguez A, Gimeno I, Flores J, Pizarro M. Outbreak of avian mycobacteriosis in 48week-old commercial layer hen flock. Avian Dis 2002; 46: 1055-1061.

21. Gerhold R, Fischer J. Avian mycobacteriosis in a wild turkey. Avian Dis 2005; 49: 164-166.

22. Kaliner G, Cooper J. Dual Infection of an African Fish Eagle with acid-fast bacilli and an Aspergillus sp. J Wildl Dis 1973; 9: 51-55.

23. Halliwell W, Graham D. Raptors (Falconiformes and Strigiformes): Bacterial Diseases of Birds of Prey: Mycobacteriosis. In: Fowler M. Zoo and Wild Animal Medicine. $2^{\text {nd }}$ ed. Philadelphia: W.B. Saunders Company; 1986. p. 413-414.

24. Tell L, Foley J, Needham M, Walker R. Comparison of four rapid DNA extraction techniques for conventional polymerase chain reaction testing of three Mycobacterium spp. that Affect Birds. Avian Dis 2003; 47: 1486-1490.

25. VanDerHeyden N. Clinical manifestations of mycobacteriosis in pet birds. Semin Avian Exotic Pet Med 1997; 6(1): 18-24.

26. Fowler M. Zoo and Wild Animal Medicine. $2^{\text {nd }}$ ed. Philadelphia: W.B. Saunders Company; 1986. p. $17,65,351$.

27. Sykes G. Mycobacteriosis in a Red-Tailed Hawk (Buteo jamaicensis). J Wildl Dis 1982; 18(4): 495-499.

28. Bougiouklis P, Brellou G, Fragkiadaki E, Iordanidis P, Vlemmas I, Georgopoulou I. Outbreak of avian mycobacteriosis in a flock of two-year-old domestic pigeons (Columba livia f. domestica). Avian Dis 2005; 49: 442-445.

29. Tell L, Ferrell S, Gibbons P. Avian mycobacteriosis in free-living raptors in California: 6 Cases (1997-2001). J Avian Med Surg 2004; 18(1): 30-40.

30. Allchurch A. Zoological parks in endangered species recovery and conservation. In: Aguirre A Ostfeld R, Tabor G, House C, Pearl M. Conservation Medicine, Ecological Health in Practice. New York: Oxford University Press; 2002. p. 278.

31. Smit T, Eger A, Haagsma J, Bakhuizen T. Avian mycobacteriosis in wild birds in the Netherlands. J Wild Dis 1987; 23(3): 485-487.

32. Leite C, Souza C, Leite S. Identification of mycobacteria by thin layer chromatographic analysis of mycolic acids and conventional biochemical method: four years of experience. Mem Inst Oswaldo Cruz 1998; 93(6): 801-805.

33. Carpenter J. Infectious and Parasitic Diseases of Cranes. In: Fowler M. Zoo and Wild Animal Medicine Current Therapy 3. Philadelphia: W.B. Saunders Company; 1993. p. 229.

34. Stroud R, Thoen C, Duncan R. Avian mycobacteriosis and salmonellosis in a Whooping Crane (Grus americana). J Wildl Dis 1986; 22(1): 106-110.

35. Fowler M. Parrots, cockatoos, macaws and perching birds (psittaciformes and passeriformes): infectious and zoonotic diseases. In: Fowler M. Zoo and Wild Animal Medicine. $2^{\text {nd }}$ ed. Philadelphia: W.B. Saunders Company; 1986. p. 494-497.

36. Lairmore M, Spraker T, Jones R. Two cases of mycobacteriosis in raptors in Colorado. J Wildl Dis 1985; 21(1): 54-57.

37. Chebez J, Aguilar R. Order Falconiformes (Hawks, Eagles, Falcons, Vultures): Infectious Diseases: Avian Mycobacteriosis. In: Fowler M, Cubas Z. Biology, Medicine, and Surgery of South American Wild Animals. lowa: lowa State University Press; 2001. p 121.

38. Fowler M. Order Strigiformes (Owls): Diseases: Infectious Diseases. In: Fowler M, Cubas Z. Biology, Medicine, and Surgery of South American Wild Animals. lowa: lowa State University Press; 2001. p. 129-130. 
39. Keymer I. Palomas. En: Beynon P, Cooper J. Manual de animales exóticos. Barcelona: Harcourt Brace; 1999. p. 209.

40. Thoen C, Himes E, Barrett R. Mycobacterium avium serotype 1 infection in a Sandhill Crane (Grus canadiensis). J Wild Dis 1977; 13: 40-42.

41. Snoeyenbos G. Mycobacteriosis in a Ruffed Grouse. Bull Wildl Dis Assoc 1966; 2: 9.

42. Garcia A, LeClear C, Gaskin J. Mycobacterium avium infection in an ostrich (Struthio camelus). J Zoo Wild Med 2001; 32(1): 96-100.

43. Jensen J. Infectious and Parasitic Diseases of Ratites. In: Fowler M. Zoo and Wild Animal Medicine Current Therapy 3. Philadelphia; W.B. Saunders Company; 1993. p. 200.

44. Silveira L, Fowler M. Order Anseriformes (Ducks, Geese, Swans): Diseases: Infectious Diseases: Bacterial Diseases. In: Fowler M, Cubas Z. Biology, Medicine, and Surgery of South American Wild Animals. lowa: lowa State University Press; 2001. p. 191.

45. Mikich S, Jennings J, Cubas Z. Order Piciformes (Toucans, Woodpeckers): Infectious Diseases: Bacterial Diseases. In: Fowler M, Cubas Z. Biology, medicine, and surgery of South American Wild animals. lowa: lowa State University Press; 2001. p. 109-111.

46. Cooper J, Karstad L, Boughton E. Mycobacteriosis in Lesser Flamingoes in Kenya. J Wild Dis 1975; 11: 32-36.

47. Fowler M. Order Phoenicopteriformes (Flamingos): Diseases: Infectious Diseases. In: Fowler M, Cubas Z. Biology, Medicine, and Surgery of South American Wild Animals. lowa: lowa State University Press; 2001. p. 100-101.

48. Kock N, Kock R, Wambua J, Kamau G, Mohan K. Mycobacterium avium-related epizootic in freeranging lesser flamingos in Kenya. J Wild Dis 1999; 35(2): 297-300.

49. Sileo L, Grootenhuis J, Tuite C, Hopcraft J. Mycobacteriosis in the Lesser Flamingos of Lake Nakuru, Kenya. J Wildl Dis 1979; 15(3): 387-389.

50. VanDerHeyden N. New strategies in the treatment of avian mycobacteriosis. Semin Avian Exotic Pet Med 1997b; 6(1): 25-33.

51. Tell L, Foley J, Needham M, Walker R. Diagnosis of avian mycobacteriosis: comparison of culture, acid-fast stains, and polymerase chain reaction for the identification of Mycobacterium avium in experimentally inoculated Japanese Quail (Coturnix coturnix japonica). Avian Dis 2003; 47: 444-452.

52. Tell L Woods L, Foley J, Needham M, Walker R. A model of avian mycobacteriosis: clinical and histopathologic findings in Japanese quail (Coturnix coturnix japonica) Intravenously Inoculated with Mycobacterium avium. Avian Dis 2003; 47: 433-443.

53. Yates V, Miller $\mathrm{L}$. The isolation of avian mycobacteriosis from a starling. Bull Wildl Dis Assoc 1966; 2: 84-85.

54. Tell L, Leutenegger C, Larsen R, Agnew D, Keener L, Needham M, Rideout B. Real-time polymerase chain reaction testing for the detection of Mycobacterium genavense and Mycobacterium avium complex species in avian samples. Avian Dis 2003; 47: 1406-1415.

55. Sequeira P, Souza L, Silva M, Feres M. Mycobacterium avium restriction fragment length polymorphism-IS IS1245 and the simple double repetitive element polymerase chain reaction typing method to screen genetic diversity in Brazilian strains. Mem Inst Oswaldo Cruz 2005; 100(7): 743-748.

56. Cooper JR. Preventive Medicine in Birds of Prey. In: Fowler M. Zoo and Wild Animal Medicine. $2^{\text {nd }} \mathrm{ed}$. Philadelphia: W.B. Saunders Company; 1986. p. 403-404.

57. Crespo M, Corral R, Alzate A, Carrasquilla G, Sanchez N. Infecciones micobacterianas en pacientes infectados por el virus de la inmunodeficiencia humana en Cali, Colombia. Rev Panam Salud Publica 1999; 6(4): 1-14.

58. Castro C, Puerto G García L, Orjuela D, Polo C, Garzón M, Ribón W. Identificación molecular de micobacterias no tuberculosas mediante el análisis de los patrones de restricción, Colombia 1995-2005. Biomedica 2007; 27: 439-446.

59. Joint United Nations Programme on HIV/AIDS (UNAIDS) and World Health Organization (WHO). AIDS epidemic update: December 2007. p. 54.

60. Parkin D, Bray F, Ferlay J, Pisani P. Global Cancer Statistics, 2002. CA Cancer J Clin 2005; 55: 74-108. 